Ключевые слова: телесность, скульптура, классическое искусство, модернизм, постмодернизм, художественный образ, симулякр. R. M. Rusin, PhD, Assosiate Professor

Taras Shevchenko National University of Kyev

60, VolodymyrskaStrit, Kyev, 01033, Ukraine

\title{
CORPORALITY AS AN ATTRIBUTE OF SCULPTURE(EUROPEAN CONTEXT)
}

The historical development of art is a change of paradigms. Each paradigm contains a special understanding of art, defined both by the act of creativity itself and by the evaluation of its results. It is especially important to identify the origins of these changes, identify their stages, and determine the direction of the evolution of artistic creativity. In this context, corporeality as an artistic paradigm of European sculpture is considered in an article in the historical dimension from classics to postmodernism.

Background research driven by changes that have suffered over the past century art not only in terms of formative principles, but also in terms of being a work of art. The term "art" is not given apriori; it is inseparable from the historical conditions of its own realization and filled with different content. In ancient tradition, from which theoretical understanding of artoriginates, provides an understanding of art as mimetic activity. For plastic art of the ancient Greeks man was the epitome of all things, the prototype of all creation and the created. The human body in great shape was almost the only model of art aesthetic. The Greeks thought it only as a stature completeness.

For the Greeks, body language was the language of soul, although Greek plastics did not know what analysis characters the cult of the individual, which is typicalfor the art of modern times. Plasticity, the ancient body kinetics can be regarded as some elements of the semantic structure of a particular language as a kind of mimicry. Plastic modern European sculpture shows opposite tothe ancient classics, Christian traditional relationship of mind and body. Antiquity knew dualism of mind and body, and provided perception of the gods only in the body incarnation. Christianity brought a legislateddualism and brought early naive monism attitudeinto the historically natural decay. In the art of the Renaissance in Europe, due to rethinking of ancient Christian tradition, experience acquires the tendency of forming an image of ideal body oriented on classic examples.

In the mid-nineteenth century, under the influence of a new understanding of human corporeality was an appeal to antiquity qualitatively new level due to the growing trend of "naturalization" in human culture and criticism concerning the previous historical periods.

In the culture of the twentieth century, there was a quite relevant anthropological stance of negativism. Justification ofindividual values has led to a lack of uniform standards, because itwas perceived as an encroachment on personality. The natural beauty in all its perfection, the image of which was the purpose and content of Antiquity plasticsand the Renaissance art lost all its worthiness and has becomea subject of neglecting within the postmodernism.

Key words: corporeality, sculpture, classical art, modernism, postmodernism, artistic image, simulacrum.

удк 1:316.334

А. М. Тормахова, канд. філос. наук, асист. Київський національний університет імені Тараса Шевченка вул. Володимирська, 60, м. Київ, 01033, Україна tormakhova@ukr.net

\section{URBAN STUDIES У КОНTEКСТI TEOPIЙ ВІЗУАЛЬНИХ ПРАКТИК}

Одним $з$ провідних напрямків сучасних культурологічних досліджень є Urban studies. Метою статmі є дослідження кола проблем, пов'язаних з існуванням, функціонуванням різноманітних візуальних практик в міському просторі, та розкриття специфіки комунікації, що здійснюється за їх посередництвом. Методологія дослідження включає використання міждисциплінарного підходу, який би спирався на здобутки практичної культурології, Urban studies, естетичної теорії у працях як вітчизняних, так і західних авторів. Наукова новизна полягає в аналізі зв'язку актуальних візуальних практик, представлених в міському просторі, та інтернет-активності, що сприяє взаємовпливу цих сфер. Практична значимість полягає у тому, що результати дослідження можуть бути використані для розвитку сфери урбаністики зокрема, а також актуалізації необхідності організації міського середовища та конструювання образу міста.

Ключові слова: міський простір, візуальні практики, комунікація, Urban studies, метамодернізм.

Постановка проблеми. Актуальною тенденцією сучасного культурологічного дискурсу є зростання наукового інтересу до Urban studies. В межах цього напрямку досліджень здійснюється багатоаспектний аналіз простору людського існування: місто розглядається як суперечливе поєднання соціальних, політичних та естетичних вимірів; розкривається взаємодія урбанізації, міграції та расової/етнічної ідентичності; наголошується на зв'язку формування ринків праці та населення; акцентується увага на процесі формування у місті культурного життя та природного середовища тощо. Одним з аспектів вивчення міста $€$ розкриття специфріки становлення його візуальних фрорм та їх зв'язку з комунікативними практиками. Цей підхід до аналізу міського простору $є$ недостатньо розкритим в культурологічній думці, що й зумовлює звернення до нього.

Аналіз досліджень і публікацій. Специфіка метамодерних наративів, які характеризують стан сучасного розвитку культури загалом та мистецтва зокрема, представлена у розробках нідерландських культурологів Т. Вермьюліна і Р. Аккера. Основні напрямки становлення перспективних Urban studies окреслюють іноземні автори, зокрема У. Боуен, Р. Данн, Д. Касдан, Р. Харріс та М. Сміт. Аналіз специфріки взаємодії архітектурних просторів, сучасного мистецтва та новітніх технологій здійснюється українським дослідником О. Чепелик. В роботах вітчизняного автора А. Бєломєсяцева розглядаються філософські, правові та еко- номічні основи архітектури. Розвідки, пов'язані 3 дослідженням міського простору та його візуального компонента, здійснюють такі сучасні культурологи, як А. Костіна, Д. Южакова. Комунікативні практики та їх роль в аналізі суспільства представлені у праці В. Зотова, В. Лисенка. Проте багато аспектів, пов'язаних 3 візуальними практиками міста, а саме: специфіка комунікативного процесу та його зв'язок 3 іншими візуальними фоомами - залишаються мало дослідженими та потребують наукового обґрунтування.

Мета статті. Метою статті $€$ окреслення кола проблем, пов'язаних з існуванням, функціонуванням різноманітних візуальних практик в міському просторі, та розкриття специфріки комунікації, що здійснюється за їх посередництвом.

Виклад основного матеріалу. Більшість авторів, які займаються візуальними дослідженнями, стверджують, що в умовах сьогодення зростає роль практик, а не мистецтв. Комунікативні практики - це постійне відтворення систем комунікацій різного рівня, "впорядковані сукупності зразків раціональної діяльності, спрямованої на передачу/прийом соціально значимої інформації" [2, с. 54]. Вiзуальні практики безпосередньо пов'язані з повсякденністю, адже вони присутні в людському житті щодня. Так, міський простір, що $є$ місцем постійного перебування значної частини суспільства, постійно видозмінюється. Візуальне обличчя міста може зазнавати як значних змін, що будуть мати постійний характер, так і незначних, тих, що досить швидко минуть. Проте всі вони впливають на 
сприйняття людиною міського простору i, будучи безпосередньою частиною життєсвіту, віддзеркалюють зміну смаків, демонструють виникнення нових тенденцій, реагують на значні події культурного, політичного, економічного вимірів суспільного існування та, відповідно, є важливим об'єктом для культурологічного дослідження.

В міському просторі наявні такі форми, як монументальна архітектура, міська скульптура, ілюмінація, зовнішня реклама, садово-паркове мистецтво, стріт-арт, графріті та ін. Ці артефакти культури стають предметом аналізу різних дисциплін - естетики, культурології, основ дизайну, мистецтвознавства. Можна зазначити, що в останні десятиліття значного розвитку здобуває такий напрямок, як урбаністика (Urban studies), основним об'єктом дослідження якого виступає саме місто. У. Боуен, Р. Данн та Д. Касдан у своїй праці зазначають, що перші розробки, які можна віднести до сфери урбаністики, з'явилися в 1960-х роках. Проте досить важко казати про академічний характер подібних досліджень. "Це поле було засновано на двох пропозиціях, що приблизно фрормулюються наступним чином: по-перше, міський простір - явище, гідне дослідження, а по-друге, розвиток знань конкретно про міський простір може допомогти у вирішенні міських проблем. Незважаючи на інтелектуальну узгодженість цих положень, сфрера міських досліджень піддається критиці за те, що недостатньо осмислюється, обмежена і вузька, щоб отримати статус офріційної академічної дисципліни" [6, р. 199]. На думку культурологів, Urban studies можна розподілити на такі ланки, як: міська соціологія, географрія, економіка, управління і планування, екологічні дослідження, розвиток житла та околиць. Р. Харріс та М. Сміт переконані, що до цього переліку необхідно додати також таку сфеpy, як Urban history (історія міста), аналіз якої буде мати міждисциплінарний характер та потребуватиме знань історичного, археологічного, культурологічного, економічного характеру [7]. Варто відмітити, що в українському культурологічному дискурсі інтерес до Urban studies лише починає намічатися і на даний момент відсутній системний підхід до вивчення різноманітних явищ, пов'язаних з міським простором.

Аналізуючи міський простір, досить рідко можна казати про наявність ансамблю чи хоча б певної злагодженості форм, представлених у ньому. Кожна практика, як правило, транслює своє власне, самостійне повідомлення, спрямоване до адресата, проте не має жодного стосунку до інших об'єктів, що знаходяться поруч із ним. "Візуальні практики в міському середовищі враховують дану особливість психології сприйняття жителя мегаполіса і надають йому нескінченну кількість образів, що транслюють найрізноманітніші повідомлення" [3, с. 142]. Отже, образи, які передаються завдяки візуальним об'єктам, створюють хаотичну, яскраву, калейдоскопічну картину, що не підпорядкована єдиній логічній лінії. Так, більшість новобудівель контрастують з більш старими будинками. Спільності досягнути принципово неможливо, адже автори проектів абсолютно різні, а міські адміністрації не займаються проблемою співмірності, гармонійності та комплексності забудівель. Наріжною проблемою є надмірність рекламного контенту, який додає своїх "барв". Внаслідок змін політико-економічних чинників відбувається відмова від того чи іншого візуального контенту міста - зникають одні скульптурні композиції, а на їх місце приходять інші, більш актуальні. А. Бєломєсяцев, аналізуючи процеси, які відбуваються в українському міському просторі, зазначає, що сучасне прагнення "покращити" житлові мікрорайони 1960-1970-х pp. за допомогою зведення в них нових споруд йде не на користь житловим утворенням. "В цих мікрорайонах вже існує десятиліттями сформована своя "мікроаура", усталені стосунки між поколіннями мешканців, усталена інфраструктура, форми організації довкілля тощо. I внесення у цей середовищний мікроклімат нової незвичної (сучасної) архітектурної форми не тільки не сприятиме його покращанню, а й ризикує значно спаплюжити містобудівну і соціально складену форму. До речі, так і відбувається, коли у "радянські мікрорайони" теперішні забудовники, не рахуючись з точкою зору мешканців, прагнуть "втюхати" оригінальну за формою новобудову (саму по собі й непогану за функцією), тим самим провокуючи "забудовну війну" між мешканцями мікрорайону, районною та міською владою, в якій, як правило, перемагають мешканці" [1, с. 9-10]. Цікавим аспектом для культурологічного дослідження візуального оформлення міського простору є аналіз тих практик, в яких превалює художньо-естетична функція, а не прикладна, тобто мистецьких арт-об'єктів.

Якщо звернутись до аналізу найбільш "молодих" візуальних практик, представлених в міському просторі Києва, одними з перших на згадку приходять мурали, кількість яких за останні чотири роки надзвичайно зросла. Більшість з них розташована в історичній частині міста, яка не надто потребує подібного "прикрашання". Менша ж частина муралів розташована у "спальних" районах, їх естетична функція в даному випадку $\epsilon$ значно більшою, адже розмальовуючи однотипні сірі панельні будинки, зведені у радянські часи, митці з України, Іспанії, Аргентини, Австралії, Німеччини, Британії та Португалії прагнуть змінити образ міста. Проте не завжди вибір художників відповідає характеру місцевості, де розташовується малюнок, а також багато з них створюються похапцем, не враховуючи атмосферні умови та час проведення робіт. Наприклад, один 3 найновіших чорно-білих муралів "Дівчина зі скрипкою", створений наприкінці 2016 року, ще до свого завершення зазнав впливу опадів та почав "танути", що аж ніяк не намагався виправити чи певним чином скорегувати його творець український митець Олександр Корбан.

Проблема соціальної відповідальності митця все більш активно постає якраз у питанні оформлення міського простору. Неабиякий суспільний резонанс викликала будівля Київського академічного драматичного театру на Подолі, автором реконструкції якого став Олег Дроздов. Проект, який в технічному відношенні повинен був задовольнити потреби театральних вистав XXI століття, не відповідає загальному обличчю архітектурного комплексу Андріївського узвозу. Сутністю запропонованої реконструкції стало намагання розширити глядацьку залу, здійснити ряд технічних нововведень, які б сприяли зростанню можливостей втілення новаторських режисерських рішень. Але, виходячи з зовнішнього антуражу будівлі, яка в нижній частині нагадувала стилістику пластикового оздоблення "євробалконів", а у верхній - куб з ракушняка, її важко уявити посеред будинків, збудованих більше ніж століття тому. Подібний проект корелює 3 тенденціями, які представлені в закордонній архітектурі. Дана будівля дотична до витворів одного з провідних архітектурних бюро сучасності Herzog \& de Meuron Architekten. Ряд культурологів вказують, що мінімалістичні будівлі цих швейцарських архітекторів відповідають стилістиці метамодернізму. Нідерландські автори Т. Вермьюлін і Р. Аккер зазначають, що онтологічно метамодернізм коливається між модерном і постмодерном, між модерним ентузіазмом і постмодерністською іронією, між надією і тугою, між співчуттям і апатією, єдністю і множинністю, сукупністю і 
фррагментацією тощо. Дійсно, саме в коливаннях між модерном і постмодерном полягає сутність метамодернізму. Твори таких архітекторів, як Жак Херцог і П'єр де Мерон, є зразковими в даному випадку, їх проекти швидше за все можна назвати неоромантизмом, на думку Т. Вермьюліна і Р. Аккера. Зовнішній фасад Музею де Янг (Сан-Франциско, 2005) накритий мідними пластинами, які внаслідок окислення поступово будуть зеленіти, інтер'єр Walker Art Center (Міннеаполіс, 2005) поєднує такі природні елементи, як камені і кристали. Бібліотека Бранденбурзького технічного університету (Котбус, 2004) являє собою готичний замок з напівпрозорим фрасадом з білими символами; Пекінський національний стадіон (2008) виглядає як "темний і зачарований ліс" зблизька і як гніздо гігантського птаха - на відстані. Ці будівлі намагаються балансувати між такими протилежними полюсами, як культура і природа, кінцеве і нескінченне, звичайне й ефемерне. Автори відзначають, що досить важливим є їх дуалістичний характер, що не дає можливості виділити один з "полюсів". Якщо спробувати уявити у мініатюрі візуальне обличчя сучасного міста, воно якраз і постає як надзвичайно мозаїчне поєднання культурно-історичних пам'яток та багатоповерхівок, зліплених з бетону та скла.

Творчий метод Herzog \& de Meuron Architekten полягає у спробі створити своєрідний місток між минулим та майбутнім у кожній будівлі, "селекціонувати" нове покоління архітектурних споруд, яке б було генетично споріднене з усіма іншими об'єктами у міському просторі та гармонійно виглядало у будь-якій місцевості. Хоча, знову ж таки, варто звернути увагу на те, що більшість робіт цього архітектурного бюро розташовані подалі від історичного центру міста, як правило, розміщуючись на доволі значній території, де ніщо не заважає створити власне враження про архітектурний об'єкт. Якраз ця здатність справити враження альтернативного простору якнайкраще відповідає настановам метамодернізму. "Метамодерн слід розуміти як простірчас, який $є$ одночасно впорядкованим неврегульованим. Метамодернізм поєднує параметри сьогодення 3 інтересами майбутньої присутності, проте не має майбутнього, він зміщує кордони нашого простору з кордонами сюрреалістичного місця, яке не існує. Доля метамодерну полягає в тому, щоб окреслювати горизонт, який завжди відступає" [8]. На наше переконання, метамодерна тенденція поєднання непоєднуваного, яка широко представлена в мінімалізмі будівель Herzog \& de Meuron Architekten, що вражають своєю неординарністю та оригінальністю втілення, в українському варіанті виглядає не зовсім доцільною. І власне проблема постає не у відсутності смаку чи консервативності частини киян, які не здатні оцінити подібну новацію, а скоріше у виборі місця розташування - в старовинній частині міста, гармонійність якої порушується.

Виникнення одних візуальних об'єктів досить часто стає поштовхом до появи інших. Обговорення в медійному просторі будівлі театру сприяло утворенню величезної кількості інтернет-мемів, частина яких стали справжніми шедеврами. Їх спонтанне розповсюдження усіма можливими способами - в особистих повідомленнях, коментарях до новин, на "стіні" у соціальних мережах - підігріває інтерес до проблеми міського простору, яка досить довго не привертала уваги пересічних громадян. Власне поява будь-якої події у медійному просторі потребує швидкого реагування на неї у вигляді коментаря чи хоча б "лайка". На форумах сайтів, на сторінках та у групах в соціальних мережах можна спостерігати різні форми активності учасників. Ї̈̈ про- явами $€$ візуальні повідомлення, які можуть включати фото та відео арт-об'єкта, що поєднуються з певними "ключовими" фігурами - "носіями інформації": персонажами кінострічок, серіалів, героями рекламних роликів, публічними персонами, політиками, акторами і т.п.

Цікавим явищем сьогодення $€$ велика кількість коубів, виникнення яких так само пов'язане 3 комунікативним процесом навколо явищ міського простору та його презентацією за посередництвом різноманітних медіа. Коуби - це короткі відеоролики, що виникають як миттєва реакція користувачів мережі Інтернет на найбільш яскраві медіа-події. Сутністю коубів $є$ використання досить короткого, яскравого 3 позиції інформативної насиченості, "зацикленого" (повторюваного) уривка оригінального відеоряду, на який накладається новий звукоряд. Також можливе поєднання елементів нового, актуального відео 3 елементами інших, попередніх, проте вже добре відомих глядацькій мережевій аудиторії уривків. Зміст даних роликів пов'язаний $з$ новою інтерпретацією подій, знятих на відео та викладених у Мережу. Досить часто їх сюжети демонструють реакцію на виступи відомих політиків, акторів, персонажів фрільмів і, як правило, містять іронічний підтекст. Можливі також коуби, де основою виступає не іронізування, а скоріше акцентуація на якомусь жесті, стані, явищі, придатному для тривалого споглядання. Кількість переглядів попередніми користувачами починає зумовлювати вибір наступних, коли відповідь на запит в пошуковій системі автоматично видає той ролик, який користувався найбільшою популярністю. Ці комунікативні інтернет-практики виникають у Мережі як реакція на "зовнішні" події, проте часто вони виходять "назовні", за межі інтернет-простору - у міське середовище. Місто виступає як феномен, що не обмежується рамками своїх фрізичних кордонів, воно продовжується в онлайн-дискусіях і фантазіях про нього, які завдяки Мережі мають тенденцію швидко i неконтрольовано втілюватися в матеріальному світі. Вплив мережевої культури на фізичне існування людини проявляється насамперед у тому, що простір проживання людини стає все менш "природним", "в ньому все менше природних характеристик, фракторів клімату і ландшафту. Так, в разі конкретного прикладу "мережевого міста" його місця - моли, парки, транспортні розв'язки - буквально сконструйовані за образом і принципом Мережі" [4, с. 305]. Характерними ознаками Мережі виступають горизонтальний характер комунікації, інтерактивність, мінливість, багатовимірність. Є. Лапіна вказує на те, що для Мережі притаманне заперечення доцентрової структури, але натомість є зони найбільш інтенсивної комунікації, які можна назвати вузлами Мережі, - простори публічної сфери і місця культури споживання.

Варто відмітити, що взаємозв'язок архітектури та новітніх технологій має й інший вектор спрямованості, коли відбувається формування нової моделі урбаністичного простору - медіа-міста. Про це влучно говорить українська дослідниця О. Чепелик: "Взаємодія архітектури і мистецтва інформаційних технологій призводить до появи нових форм і подальшого розвитку різних художніх і соціальних комунікативних систем у громадських місцях міста: - public art; - медіафасади, структурні елементи архітектурного об'єкта; - імерсивні середовища" [5, с. 257]. Прикладом такого медіа-міста може служити створення імерсивних просторів, які утворюються шляхом трансформації мультимедійного середовища у реальний часопростір. Одні з перших 
подібних проектів створював Рафраель Лозано-Хеммер - канадський художник, який поєднував фрізичні будівлі та штучні віртуальні конструкції, що призводило до балансування між реальною та віртуальною архітектурою. Він "збільшував" будівлі, додаючи до них аудіовізуальні елементи заради розширення історичного, політичного чи естетичного контексту. Таким чином формується глобальне урбаністичне медіа-поле, що змінює архітектурний і суспільний простір міста.

Власне, можна відзначити, що міський простір поступово стає не тільки інтерактивним, а повною мірою перебирає на себе характеристики WEB 2.0, що означає активне переосмислення і транссоормацію довкілля, включеність міських жителів до процесу прийняття рішень, які стають нормами повсякдення. Внаслідок активного освоєння міського простору відбувається зміна звичного образу міста. Візуальні повідомлення митців, втілені у різних типах практик, часом "лунають" наче оркестрові інструменти, налаштовані у різних тональностях, створюючи какофонію, а не гармонію, що наголошує на необхідності вироблення єдиного обличчя міста, в процесі розробки якого має брати участь усе суспільство.

Висновок. Urban studies $€$ одним 3 найбільш перспективних напрямків сучасного культурологічного знання. Хоча в англо-американській традиції він вже отримав академічне забарвлення, в сучасному українському дискурсі розробка різних аспектів, пов'язаних з міським простором, лише починає набувати актуальності. Місто - це своєрідний текст, який у візуальній формі віддзеркалює зміну смаків, культурних, політико-ідеологічних, економічних чинників. Це середовище людського існування, яке виступає джерелом та фрормою комунікативного процесу. Місто та міські публічні простори відіграють значну роль у формуванні взаємодії в межах суспільства. Однією з нагальних проблем практичної культурології загалом та сфери урбаністики зокрема має бути питання організації міського середовища та конструювання образу міста.

\section{СПИСОК ВИКОРИСТАНИХ ДЖЕРЕЛ}

1.Бєломєсяцев А.Б. Економічні основи архітектури / А. Б. Бєломєсяцев. - К.: Фенікс, 2008. - 400 с.

2. Зотов В. В., Лысенко В. А. Коммуникативные практики как теоретический конструкт изучения общества / В.В.Зотов, В.А.Лысенко // Теория и практика общественного развития. - 2010. - № 3. - С. 53-55.
3. Костина Д., Южакова Е. Визуальные практики в городском пространстве: стратегии функционирования и практики освоения / Д. Костина, Е. Южакова // Известия Уральского Федерального университета. Серия 1. Проблемы образования, науки и искусства. 2013. - № 1 (110). - С. 141-148.

4. Лапина-Кратасюк Е. "Интерактивный город": сетевое общество и публичные пространства мегаполиса / Е. Лапина-Кратасюк // Микроурбанизм. Город в деталях / Сб. статей; [под отв. редакцией О. Бредниковой, О. Запорожец]. - М.: Новое литературное обозрение, 2014. - С. 300-315.

5. Чепелик О. В. Взаємодія архітектурних просторів, сучасного мистецтва та новітніх технологій, або Мультимедійна утопія / О. В. Чепелик. - К.: Хімджест, 2009. - 272 с.

6. Bowen W. M., Dunn R. A., Kasdan D. O. What is "urban studies"? Context, internal structure, and content / W. M. Bowen, R. A. Dunn, D. O. Kasdan // Journal of Urban Affairs. - 2010. - 32(2). - P. 199-227.

7. Harris R., Smith M. E. The history in urban studies: a comment / R. Harris, M. E. Smith // JOURNAL OF URBAN AFFAIRS. - 2011, Volume 33, Number 1. - P. 99-105

8. Vermeulen $T$, van den Akker R. Notes on metamodernism [Електронний ресурс] / T. Vermeulen, R. van den Akker // AESTHETICS \& CULTURE, Vol. 2, 2010. - Режим доступу: http://www.aestheticsandculture.net/index.php/jac/article/view/5677/6306.

\section{REFERENCES}

1. Byelomyesyacev, A. B. (2008) Ekonomichni osnovy arxitektury [Economic fundamentals of architecture]. Kyiv, Feniks.

2. Zotov, V. V., Lysenko V. A. (2010) Kommunikativnye praktiki kak teoreticheskij konstrukt izuchenija obshhestva [Communicative practices as a theoretical construct for the study of society]. Theory and practice of social development, 3, 53-55.

3. Kostina D., Juzhakova E. (2013) Vizual'nye praktiki v gorodskom prostranstve: strategii funkcionirovanija i praktiki osvoenija [Visual practices in the urban space: strategies for the functioning and practice of development]. News of the Ural Federal University. Series 1. The problems of education, science and art, 1, 141-148

4. Lapina-Kratasjuk, E. (2014) "Interaktivnyj gorod": setevoe obshhestvo i publichnye prostranstva megapolisa. [Interactive city: a network society and public spaces of a megacity]. Microurbanism. City in details. Moskow, Novoe literaturnoe obozrenie, 300-315.

5. Chepelyk, O. V. (2009) Vzayemodiya arxitekturnyx prostoriv, suchasnogo mystetstva ta novitnix texnologij, abo Mul'tymedijna utopiya [Interaction between architectural spaces, contemporary art and the latest technology, or multimedia utopia]. Kyiv, Ximdzhest.

6. Bowen, W. M., Dunn, R. A., Kasdan, D. O. (2010). What is "urban studies"? Context, internal structure, and content. Journal of Urban Affairs, 32(2), 199-227.

7. Harris, R., Smith, M. E. (2011) The history in urban studies: a comment. Journal of urban affairs, Vol. 33, 1, 99-105.

8. Vermeulen, T, van den Akker, R. (2010) Notes on metamodernism. Aesthetics \& culture, Vol. 2. Retrieved from http://www.aestheticsandculture. net/index.php/jac/article/view/5677/6306.

Надійшла до редколегії 16.05.17

А. Н. Тормахова, канд. филос. наук, ассист.

Киевский национальный университет имени Тараса Шевченко ул. Владимирская, 60, г. Киев, 01033, Украина

\section{URBAN STUDIES В КОНTЕКСТЕ ТЕОРИЙ ВИЗУАЛЬНЫХ ПРАКТИК}

Одним из ведущих направлений современных культурологических исследований является Urban studies. Целью статьи является исследование круга проблем, связанных с существованием, функционированием различных визуальных практик в городском пространстве, и раскрытие специфики коммуникации, осуществляемой при их посредничестве. Методология исследования включает обращение к междисциплинарному подходу, который бы опирался на достижения практической культурологии, Urban studies, эстетической теории в работах как отечественных, так и западных авторов. Научная новизна заключается в анализе связи актуальных визуальных практик, представленных в городском пространстве, и форм интернет-активности, способствующей взаимовлиянию этих сфер. Практическая значимость заключается в том, что результаты исследования могут быть использованы для развития сферы урбанистики в частности, а также актуализации вопроса организации городской среды и конструирования образа города.

Ключевые слова: городское пространство, визуальные практики, коммуникация, Urban studies, метамодернизм.

A. M. Tormakhova, PhD, Assistant Professor

Taras Shevchenko National University of Kyiv

60, Volodymyrska Street, Kyiv, 01033, Ukraine

\section{URBAN STUDIES IN THE CONTEXT OF THEORIES OF VISUAL PRACTICES}

One of the leading trends in contemporary cultural studies is the appeal to the field of visual. The purpose of the article is to investigate the range of problems associated with the existence, functioning of various visual practices in the urban space and the disclosure of the specifics of communication carried out through their intermediation. In urban space, there are many forms, such as monumental architecture, urban sculpture, outdoor illumination, landscape art, street art, graffiti and others. These artifacts are the subject of cultural research within different disciplines aesthetics, cultural studies, design, and art. It may be noted that in recent decades, significant development gets such a direction as Urban Studies, in which the focus of research serves the city. The methodology of the study includes an appeal to an interdisciplinary approach that relies on the achievements of practical cultural studies, Urban studies, and aesthetics theory by Ukrainian and Western authors. Scientific novelty consists in analyzing the connection of actual visual practices presented in the urban space and forming of Internet activity, which facilitates the mutual influ- 
ence of these spheres one on another. The author noted that urban space is gradually becoming not only interactive, but also fully assuming the characteristics of WEB 2.0, which means active rethinking and transforming the environment, urban residents involvement in decision-making that becomes a norm of everyday life. City is a kind of text that reflects changing tastes, political and economic factors in visual form. Town and city public spaces play an important role in shaping the interaction within society. One of the pressing problems of practical cultural studies in general and urban areas in particular, should be integrated into organization of the urban environment and design the image of the city. The practical significance lies in the fact that the results of the research can be used in developing the urban sphere in particular and in actualizing the issue of organizing the urban environment and constructing the image of the city.

Key words: urban space, visual practices, communication, Urban studies, metamodernizm. 